\title{
Democratic Values Among Chinese People
}

Analysis of a public opinion survey

\section{Lu Chunlong}

\section{(2) OpenEdition}

\section{Journals}

Electronic version

URL: http://journals.openedition.org/chinaperspectives/413

DOI: 10.4000/chinaperspectives.413

ISSN: 1996-4617

\section{Publisher}

Centre d'étude français sur la Chine contemporaine

\section{Printed version}

Date of publication: 1 October 2004

ISSN: 2070-3449

\section{Electronic reference}

Lu Chunlong, «Democratic Values Among Chinese People», China Perspectives [Online], 55

september - october 2004, Online since 29 December 2008, connection on 28 October 2019. URL

http://journals.openedition.org/chinaperspectives/413; DOI : 10.4000/chinaperspectives.413

This text was automatically generated on 28 October 2019 .

(c) All rights reserved 


\section{Democratic Values Among Chinese People}

Analysis of a public opinion survey

\section{Lu Chunlong}

1 Since 1978, China has experienced economic marketisation and a degree of political liberalisation ${ }^{1}$, and the importance of Maoist ideology has diminished in people's daily life. Recent studies on political culture, while not comprehensive, have suggested the emergence of democratic values ${ }^{2}$, and thus, present a picture of hope for the prospect of Chinese democracy. The existing literature pays little attention to the origins of these democratic values, although studies have suggested that education, urban/rural residence and Party/non-Party membership are factors that have an impact on such an outcome ${ }^{3}$.

2 This study is based on the scientifically sampled national survey of public opinion in China, the World Values Survey (WVS) $2001{ }^{4}$. WVS 2001 China Survey in June 2001 has been implemented by the Research Center for Contemporary China at Peking University. The sample consists of 1,000 respondents distributed in proportion to both urban and rural populations to be representative of the whole adult population (18 years old and over). The main objective of this study is to examine the origins of democratic values in China and provide evidence to show the types of people likely to support these values.

Why are democratic values important?

3 When explaining the conditions that give rise to American democracy, Tocqueville has emphasised the importance of egalitarian mores in American society 5. Contemporary democracy theorists have reached a consensus that a set of pro-democratic values held at the individual level is conducive to the installation and consolidation of democracy. Democracy theorists identify certain distinctive clusters of democratic attitudes that are widely held across individuals. These clusters of democratic attitudes are durable and form subjective world orientations that are highly resistant to change, and are seen as the driving force for democratic development ${ }^{6}$. 
4 Almond and Verba were the first to systematically consider the concept of civic culture as a means to identify civic cultural attributes which are conducive to durable and stable democracy ${ }^{7}$. They assert that the civic culture is a mixed political culture. The participant role has been added to the subject and parochial roles. Gibson uses seven sub-dimensions-support for norms of democracy, political tolerance, valuation of liberty, support for competitive elections, rights consciousness, support for dissent, and support for independent media- to measure democratic beliefs of the public and establish the linkages between these democratic beliefs and democracy ${ }^{8}$. Putnam operationalises civicness by following indicators: vibrancy of associational life, newspaper readership, electoral turnout, and lack of preference voting ${ }^{9}$. Putnam pays attention to the roles of voluntary associational life. The horizontally organised associations build norms of generalised reciprocity and interpersonal trust, which are favourable to durable and effective democracy. These seminal works lay out the basic framework for positivist analysis of democratic values.

Chinese traditional political culture is often regarded as an obstacle to democratic transition ${ }^{10}$. Confucian culture "emphasised the group over the individual, authority over liberty, and responsibilities over rights" and "lacked a tradition of rights against the state". In Confucian society, "harmony and cooperation were preferred over disagreement and competition," "the maintenance of order and respect for hierarchy were central values" ${ }^{11}$. Therefore, China's traditional political culture is attributed as being "non-democratic".

6 Studies nevertheless have suggested the emergence of democratic values in China. These studies based their conclusions on the results of public opinion surveys and suggest that Chinese political culture is in transition. For example, Ogden suggests "China has inklings of a democratic political culture in certain respects and not in others" ${ }^{12}$.

Measuring the support of democratic values

7 Nathan and Shi were the first to attempt a study of the democratic orientations of Chinese people. They measure the support of democratic values from three subdimensions: the perceived impact of government, political efficacy and political tolerance ${ }^{13}$. Wang and his associates adopt the same measurement criteria ${ }^{14}$. Shi's more recent works are also influenced by this method with an emphasis on political efficacy ${ }^{15}$. Nonetheless, this approach is not directly aimed at capturing the democratic values themselves. With an emphasis on the political efficacy, this measurement realises the importance of participant political culture in democracy, but is neither complete nor accurate in capturing democratic orientations.

8 Chen and Zhong's measurement of democratic values is more direct, and accurate, following three sub-dimensions: support for competitive elections of government officials, support for equal protection and rights for all people, and support for an independent media ${ }^{16}$. This measurement touches important aspects of a democratic culture. However, the support of norms of democracy, which is critical for measuring democratic values, has been left behind ${ }^{17}$.

Dowd and his associates use an open question: "which of the following values is most important?", and put political democracy and individual freedom together with public order, fair administration of justice, social equality, and national peace and prosperity ${ }^{18}$ to measure the support of norms of democracy directly. Even though a step on from 
Chen and Zhong, this measurement is questionable. It fails to make distinctions between affective support of democracy and evaluative support of democracy.

Drawing upon the seminal works by Almond and Verba, Gibson, and Putnam, this study will measure the democratic values of Chinese people from following two subdimensions: the acceptance of democratic norms (affective support) and the judgement about the performance of democracy (evaluative support).

11 Why this distinction? Some recent studies suggest that the support for democratic principles is very different from evaluations of how democracy will perform in practice 19. Our method allows respondents to "express doubts about democracy, without directly rejecting democratic principles", and to focus "on broad features of democratic governance, and not on short-term judgments about specific governments" ${ }^{20}$. In this study, the affective support of democracy is measured by the survey question regarding "having a democratic political system", while the evaluative support of democracy is measured by the survey question stating that "democracy may have problems but it's better than any other form of government". The main concern of this study is to provide evidence about what sorts of people are likely to hold values considered democratic.

Three theories of the origins of democratic values

12 1) This theory emphasises the importance of socio-economic factors such as income, education and age. According to this theory, the more wealthy, well-educated and young the people are, the more they are likely to support democracy. With the continued economic development of China, there should be more signs of attraction to democracy or values considered democratic as a result.

Nathan and Shi have found that the perceived impact of government varies substantially with the level of education. They suggest that the level of political tolerance is likely to increase as older less-educated people are replaced by younger, better educated people. Even though less-educated people have a relatively low sense of the government's impact, relatively low internal efficacy, relatively low political tolerance, and relatively high confidence in the government, Nathan and Shi are optimistic about the prospect for Chinese democracy. They conclude that Chinese political culture will move closer to the patterns characteristic of democratic countries as the economy grows ${ }^{21}$.

In a more recent study, Shi also finds that higher levels of education and income play a significant role in making people transcend their traditional culture. People with higher education and income not only tend to perceive their relationship with authority as reciprocal but are also more willing to enter into conflict with others to assert their interests ${ }^{22}$.

After presenting the fact that well-educated and wealthy Chinese people are more likely to possess democratic values, $\mathrm{Chu}$ and Chang conclude: "socioeconomic development is positively correlated with demand for democratic principles, suggesting that modernisation generally facilitates the growth in democratic-value orientation" ${ }^{23}$. All these studies suggest that well-educated, urban and wealthy people have a relatively stronger orientation towards democratic values than the rest of Chinese.

On the other hand, the multivariable analysis offered by Dowd and his associates finds the opposite direction between education and political democracy, and between income and political democracy. Dowd finds no evidence "to suggest that there will be 
increasing pressure for democratisation based on generational replacement effects" ${ }^{24}$. The positive relationship between age and the probability of selecting political democracy as the most important value may suggest "there will not be any long-term, generational-replacement-driven pressure for democratization" ${ }^{25}$.

2) This theory emphasises the importance of middle class ${ }^{26}$. For Lipset, the middle class is the friend of democracy ${ }^{27}$. Moore's declaration, "no bourgeois, no democracy" touched on the hypothesis about the democratic impulses of middle class ${ }^{28}$. Glassman and Huntington both recognise that middle class has particular affinities with democracy ${ }^{29}$.

With China's economic development, so the country's middle class has grown significantly, both in absolute number and in percentage relative to the whole population. In our study we consider middle class as comprised mainly of managerial personnel, private entrepreneurs, professionals, civil servants, and getihu ${ }^{30}$. This social class owns most of the economic and cultural capital, and limited political capital. We have chosen occupation as the main criteria to determine position in the social space because it ties together the three dimensions: political, economic and cultural capital. It is difficult to evaluate precisely the degree of support for democratic values among the middle class. For Glassman, China's middle class should have a high level of democratic values, since there is a global convergence of democratic values among the middle classes across the world ${ }^{31}$. Since middle class engenders a high level of education and income, we would expect it to hold a higher level of democratic beliefs. However, such extrapolation is impossible ${ }^{32}$.

14 3) The emphasis in this theory is on the importance of the working class. Collier, Rueschemeyer and the Stephens emphasise the importance of the working class in the process of democratisation instead of political elites ${ }^{33}$. They suggest that "the relative size and the density of organisation of the working class-of employed manual labor outside of agriculture-are of critical importance for the advance of democracy" ${ }^{34}$. It is the working class that fights for democracy while the bourgeoisie and urban middle class, that benefited from the status quo, nearly without exception, resist democracy, once their own interests are secured ${ }^{35}$.

With the economic development, China's working class has changed fundamentally. The reforming of state and collective firms has altered the pattern of "organised dependence" and the paternalism characteristic of state-labor relations in Mao's era ${ }^{36}$. In Mao's era, China's working class benefited from the regime; by contrast, in the reform era, China's working class is changing from being beneficiaries to becoming those losing out. China's working class has become the subordinate class and its discontent is rising. Lee's study records different forms of labour struggles; everyday workplace resistance, petitions, work stoppages, strikes, public protest, violence, independent unionism. However, even though rising worker discontent is visible, the likelihood of mass mobilisation of workers against the state appears low ${ }^{37}$. Lee's conclusion is very cautious: on the one hand, a more restive Chinese working class is in the making, while the emergence of a labour movement against the regime is yet to come $^{38}$.

16 Several studies suggest that the Chinese regime has lost the political support of the working class ${ }^{39}$. "China's political leaders can no longer take comfort in their ability to turn to the workers for support when facing crisis. Instead, they must worry about whether or not they can maintain control over their increasingly unhappy and 
fractious proletariat" ${ }^{40}$. The success of China's economic reforms is paradoxical: the leaders intended to increase support for the regime by initiating reform, but the reforms have instead gradually eroded it ${ }^{41}$.

The empirical survey

In our study, the support of democratic values is measured by the following two survey questions that consider: "Having a democratic political system" and "Democracy may have problems but it's better than any other form of government". Those saying that having a democratic political system is "very good" or "fairly good" were coded 1, and those considering it "bad" or "very bad" were coded 0 . Those choosing "agree strongly" or "agree" to respond to the statement that democracy may have problems but it's better than any other form of government were coded 1, while those who "disagree strongly" or "disagree" were coded 0.

Treating "Don't Know" (DK) answers as "missing" gave a result of a reasonably high affective and evaluative support for democracy. Of respondents, $96.3 \%$ supported "Having a democratic political system" (Table 1), while 89.9\% agreed that "Democracy may have problems but it's better than any other form of government" (Table 2). Inglehart and his associates, as well as Dalton and Shin report this finding ${ }^{42}$. The percentage of DK responses for both questions was $23.9 \%$ and $34.6 \%$ respectively (Table 3 and Table 4). If we treat DK responses as a valid and separate answer, the statistical result is quite different: $73.3 \%$ of respondents supported "Having a democratic political system" (Table 3 ) and 58.8\% agrees that "Democracy may have problems but it's better than any other form of government" (Table 4). These figures reveal a higher level of democratic orientation than existing literature suggests.

1. Affective support of democracy

Frequency of choice of "Having a democratic political system"

"don't know" (DK) considered as missing

\begin{tabular}{lcccc} 
& Yes & No & Total \\
\hline Frequency & 733 & 28 & 761 \\
\hline Percentage & 96.3 & 3.7 & 100 \\
\hline
\end{tabular}

2. Evaluative support of democracy

Frequency of choice of "Democracy may have problems but it's better than any other form of government"

"don't know" (DK) considered as missing

\begin{tabular}{lcccc} 
& Yes & No & Total \\
\hline Frequency & 587 & 66 & 653 \\
\hline Percentage & $\frac{69.9}{10.1}$ & 100 \\
\hline
\end{tabular}


3. Affective support of democracy

Frequency of choice of "Having a democratic political system"

"don't know" (DK) answers considered valid

\begin{tabular}{|c|c|c|c|c|}
\hline & Yes & No & DK & Total \\
\hline Frequency & 733 & 28 & 239 & 1000 \\
\hline Percentage & 73.3 & 2.8 & 23.9 & 100 \\
\hline
\end{tabular}

4. Evaluative support of democracy

Frequency of choice of "Democracy may have problems but it's better than any other form of government"

"don't know" (DK) answers considered valid

\begin{tabular}{|c|c|c|c|c|}
\hline & Yes & No & DK & Total \\
\hline Frequency & 587 & 66 & 346 & 999 \\
\hline Percentage & 58.8 & 6.6 & 34.6 & 100 \\
\hline
\end{tabular}

As we enter the twenty-first century, democracy has become a basic value ${ }^{43}$. No wonder then that respondents showed a high level of affective and evaluative support for democracy-Chen and Zhong reported a similar outcome even though their measurement did not cover support of norms of democracy ${ }^{44}$. Moreover, at a time when the Chinese government is more ready to talk about "socialist democracy", "democracy" has thus become a legitimate and popular word, even though the meaning may be differ from that applied to the word and the concept as used in the Western world. Thus, when Chinese citizens express support for democracy it may be that support is for a meaning different to that understood by a citizen of an established, advanced industrial democracy ${ }^{45}$.

Interpretation of DK responses is a challenge. In the Chinese context, DK can be interpreted in three different ways. Some respondents were unable to answer the question due to lack of political knowledge. Others have some knowledge about democracy and its performance, but no clear-cut idea about the meaning of support of democracy. The third sort of DK is not truly a DK. Under a Communist authoritarian regime, outright support of democracy is still believed to involve political risk. Thus, even though supporters of democracy, these respondents would have withheld their true opinion through caution.

21 This survey does not provide a measurement to identify these three types of DK responses. However, one can assume that ${ }^{46}$ the first type of DK is associated with less income, education and older age. As members of the working class tend to be less educated and less wealthy, it is assumed that most of the responses given by the respondents in this group were of the first type. The DK responses of younger, wealthier and better educated respondent were of the second and third types. While they have the political knowledge to decide their support of democracy, they may refuse to answer due to the consideration of potential political risk. They may also feel somewhat ambivalent, perhaps worrying that the Chinese path to democracy would engender political instability which could endanger their economic well-being. Thus we 
considered most of the middle class DK responses to belong to the second and third type of DK.

This study includes income, education and age as independent variables. The respondents are divided into three age cohorts (18-29 years old, 30-49 years old, and over 50), and into three categories of monthly income (less than 500 yuan to 4,000 yuan; 4,001 to 10,000 yuan; 10,001 to more than 100,000 yuan). The education variable is recoded into three categories: inadequately completed elementary education and completed (compulsory) elementary education; completed secondary school: technical/ vocational and completed secondary school: university-preparatory; some university without degree/higher education and university with degree/higher education.

Table 5 crosses the results of responses to "Having a democratic political system" with the independent variables. It suggests the following conclusions. First, age is negatively associated with acceptance of democratic principles. It does support the generationalreplacement theory. Given that most of the older generation's DK responses belong to the first type of response, and part of the younger generation's DK responses belong to the third type of response, we are confident in concluding that the Chinese younger generation do have a higher level of affective support for democratic principles. Second, the hypothesis that the Chinese middle class has elective affinities of democracy is supported. Third, when compared with the middle class, the working class has a lower level of affective support of democracy. Four, those with lower incomes have a lower level of affective support for democratic principles. Finally, those with a lower level of education have a lower level of affective support for democratic principles than those with a higher level of education.

\section{Affective support of democracy and socio-economic variables}

\begin{tabular}{|c|c|c|c|c|}
\hline \multirow[t]{2}{*}{$\%$} & & \multicolumn{3}{|c|}{$\begin{array}{l}\text { "Having a democratic } \\
\text { political system" }\end{array}$} \\
\hline & & Yes & No & $\begin{array}{l}\text { Don't } \\
\text { know }\end{array}$ \\
\hline \multirow[t]{3}{*}{ Income } & lower & 2.9 & 67.7 & 33.3 \\
\hline & middle & 2.6 & 76.5 & 20.9 \\
\hline & upper & 3.4 & 86.8 & 9.8 \\
\hline \multirow[t]{3}{*}{ Education } & lower & 2.9 & 57.7 & 39.5 \\
\hline & middle & 2.6 & 83.9 & 13.5 \\
\hline & higher & 4.7 & 93.0 & 2.3 \\
\hline \multirow[t]{3}{*}{ Age } & $18-29$ & 4.6 & 83.0 & 12.4 \\
\hline & $30-49$ & 2.3 & 72.0 & 25.7 \\
\hline & $50+$ & 2.6 & 68.4 & 29.1 \\
\hline \multicolumn{2}{|c|}{ Middle class } & 2.9 & 88.0 & 90.1 \\
\hline \multicolumn{2}{|c|}{ Non middle class } & 2.8 & 70.2 & 27.0 \\
\hline \multicolumn{2}{|c|}{ Working class } & 2.6 & 71.0 & 26.4 \\
\hline \multicolumn{2}{|c|}{ Non working class } & 2.9 & 73.9 & 23.3 \\
\hline
\end{tabular}

Table 6 crosses the responses to "Democracy may have problems but it's better than any other form of government" with the same variables. First, age is negatively associated with evaluative support of democratic principles. It does support the 
generational-replacement theory. The pretty high percentage of DK responses among the older generation respondents can be explained by the fact that the evaluation of democracy involves more political knowledge than an acceptance of democracy. Second, there is strong evidence that the Chinese middle class tends to evaluate democracy as the better form of government. Third, the working class has a lower level of evaluative support of democracy, compared with the middle class. Four, those with lower incomes offer a lower level of evaluative support for democratic principles, while those with higher incomes show a higher level of evaluative support for democratic principles. Five, those less educated show a lower level of evaluative support for democratic principles than those more highly educated.

\section{Evaluative support of democracy and socio-economic variables}

\begin{tabular}{|c|c|c|c|c|}
\hline & & No & Yes & $\begin{array}{l}\text { Don't } \\
\text { know }\end{array}$ \\
\hline \multirow[t]{3}{*}{ Income } & lower & 4.0 & 47.7 & 48.3 \\
\hline & middle & 8.4 & 62.2 & 29.4 \\
\hline & upper & 7.7 & 75.6 & 16.7 \\
\hline \multirow[t]{3}{*}{ Education } & lower & 5.0 & 41.6 & 53.3 \\
\hline & middle & 7.6 & 70.1 & 22.3 \\
\hline & higher & 9.3 & 83.7 & 7.0 \\
\hline \multirow[t]{3}{*}{ Age } & $18-29$ & 11.9 & 66.3 & 21.8 \\
\hline & $30-49$ & 5.2 & 59.4 & 35.3 \\
\hline & $50+$ & 5.6 & 50.9 & 43.6 \\
\hline \multicolumn{2}{|c|}{ Middle class } & 7.4 & 78.3 & 14.3 \\
\hline \multicolumn{2}{|c|}{ Non middle class } & 6.4 & 54.6 & 39.0 \\
\hline \multicolumn{2}{|c|}{ Working class } & 5.2 & 55.2 & 39.6 \\
\hline \multicolumn{2}{|c|}{ Non working class } & 6.9 & 59.6 & 33.5 \\
\hline
\end{tabular}

This study finds that the Chinese middle class is positively associated with democratic values. The Chinese middle class does accept democracy as a desirable political system and strongly evaluates democracy as a better form of government. This finding confirms the theory on the support of democracy by the middle class as presented by the literature on democracy and discredits the argument that the Chinese middle class is anti-democratic or undemocratic by nature ${ }^{47}$. For example, Goodman argues that "the new middle classes, far from being alienated from the Party-state or seeking their own political voice, appear to be operating in close proximity and through close cooperation" ${ }^{48}$. It is suggested that since the reforms launched in 1978, China has gradually adopted corporatist institutions to influence the development of the middle class ${ }^{49}$. As a result, the middle class depends heavily on the Party-state and cannot become a vocal supporter of democracy in the future. This argument is refuted.

The finding that age is negatively associated with democratic-value orientation confirms the generation-replacement theory. The generation-replacement theory suggests that younger Chinese people are more highly educated and more likely to accept democratic ideas, thus they are more favourably disposed towards democracy. 
This finding contradicts the argument offered by Friedman and Zhao that the Chinese younger generation is "nationalists first, democrats second". According to Friedman and Zhao, the Chinese government has taken nationalism to block Western influences and regain its legitimacy in the 1990s ${ }^{50}$. Thus, the younger Chinese generation educated in the 1990s have been indoctrinated with a strong sentiment of nationalism. As a result, "many of them would emphasize that 'they are patriots first and democrats second.' Talking about democracy has almost become forbidden among many Chinese students. It may be considered as unpatriotic, as nationalism has come to be dominant in the thoughts of Chinese intellectuals" ${ }^{51}$.

This study will not go into detail about the subtleties and complications of nationalism. Drawing upon the existing empirical studies on nationalism ${ }^{52}$, this study uses two questions to measure nationalism: 1) How proud are you to be Chinese?; and 2) of course we all hope that there will not be another war, but if it were to come to that, would you be willing to fight for your country? ${ }^{53}$. The result between age and nationalist sentiment in Table 7 suggests that there is no significant generational difference in nationalist sentiment; and that all generations have a pretty high nationalist sentiment. The co-existence of high democratic orientations and nationalist sentiments in Chinese younger generations may suggest that the younger generation is both nationalistic and democratic.

\section{Age and nationalism}

\begin{tabular}{|c|c|c|c|}
\hline & $18-29$ & $30-49$ & $\begin{array}{c}50 \\
\text { and }+\end{array}$ \\
\hline Low nationalism & $2.3 \%$ & $1,1 \%$ & $1.5 \%$ \\
\hline Medium nationalism & $16.7 \%$ & $16,4 \%$ & $21.0 \%$ \\
\hline High nationalism & $81.0 \%$ & $82,4 \%$ & $77.5 \%$ \\
\hline
\end{tabular}

People with lower incomes and lower level of education show a lower level of support for democracy and a high percentage DK response. One explanation could be that such respondents usually lack the political knowledge and consequentially are unable to form a concrete opinion. Education plays a critical role in influencing support of democracy. Highly educated Chinese people show the highest level of support of democracy. An explanation could be that education is directly associated with political knowledge and competence. The high percentage DK response to acceptance and evaluation of democracy by those with middle incomes can be explained partly by the following two points: they either worry about the political risk to themselves or the risk to their economic well-being.

The working class shows a lower level of affective and evaluative support of democracy compared to the middle class. The high percentage DK response among the working class can be explained by two points: first, the working class is less wealthy and less educated and often lacks the political knowledge to enable a definite answer to be given to both questions; second, the working class needs organisations to empower itself and shape its democratic values ${ }^{54}$. The organisation of the Chinese workers, the All-China Federation of Trade Unions (ACFTU), far from being an independent organisation, is a corporatist institution controlled by the Chinese government. The ACFTU, licensed by the government and under directives from the Chinese government regulates the 
activities of Chinese workers on behalf of the government ${ }^{55}$. As a result, the Chinese working class lacks the organisations to rouse its interest in democracy.

Conclusion and implication

Some findings of this study may be emphasised. First, the Chinese middle class has the highest level of support of democracy. However, this does not mean that this social group will rise against the current regime to fight for democracy. For the middle class to play a critical role in promoting democracy depends on other factors, such as the setting-up of independent and autonomous civil organisations to co-ordinate its collective behaviour. Second, the Chinese working class has exhibited a lower level of support of democracy compared with the middle class. Even though the working class has gradually retracted its political support for the regime since 1978, there are no organisations to rouse its interest in democracy. Third, younger well-educated chinese are more ready to accept democratic values and believe that Western democracy is a better form of governance. This finding confirms the generational-replacement theory. But the younger generation is in fact both nationalistic and democratic. Fourth, education plays a critical role in the support of democracy. The better educated people are, the higher the level of support of democracy they exhibit. Overall, this study shows prospects democracy in China.

\section{NOTES}

1. Tong Yanqi, Transitions from State Socialism: Economic and Political Chang in Hungary and China, Lanham, Rowman \& Littlefield, 1997.

2. Chu Yun-han and Chang Yu-tzung, "Culture Shift and Regime Legitimacy: Comparing Mainland China, Taiwan, and Hong Kong", in Shiping Hua, (ed.), Chinese Political Culture, 1989-2000, Armonk, ME Sharpe, 2001, pp. 320-347; Daniel V. Dowd, Allen Carlson, and Mingming Shen, "The Prospects for Democratization in China: Evidence from the 1995 Beijing Area Study", in Suisheng Zhao, (ed.), China and Democracy: Reconsidering the Prospects for a Democratic China, New York, Routledge, 2000, pp. 189-206; Andrew J. Nathan and Tianjian Shi, "Cultural Requisites for Democracy in China: Findings from A Survey”, Daedalus, Vol. 122, No. 2, 1993, pp. 95-123; Suzanne Ogden, Inklings of Democracy in China, Cambridge, Harvard University Asia Center, 2002; Shi Tianjian, "Cultural Values and Democracy in the People's Republic of China", China Quarterly, Vol. 162, 2000, pp. 540-559; Chen Jie and Zhong Yang, "Defining the Political System of Post-Deng China: Emerging Public Support for a Democratic Political System", Problems of Post-Communism, Vol. 45, No. 1, 1998, pp. 30-42; Yanlai Wang, Nicholas Rees and Bernadette Andreosso-O'Callaghan, “Economic Change and Political Development in China: Findings from a Public Opinion Survey", Journal of Contemporary China, Vol. 13, No. 39, 2004, pp. 203-222.

3. Chu and Chang, op. cit.; Dowd and al., op. cit.; Nathan and Shi, op. cit.; Shi, op. cit.; Chen and Zhong, op. cit.

4. Ronald Inglehart et al., World Values Surveys and European Values Surveys, 1999-2001 [Computer file], ICPSR Version, Ann Arbor, Institute for Social Research 
[producer], 2002, Ann Arbor, Inter-university Consortium for Political and Social Research [distributor], 2004.

5. Alexis de Tocqueville, Democracy in America, New York, Harper and Row, 1966, esp. Vol. I.

6. Robert W. Jackman and Ross A. Miller, "A Renaissance of Political Culture?" American Journal of Political Science, Vol. 40, No. 3, 1996, pp. 632-659.

7. Gabriel Almond and Sidney Verba, The Civic Culture: Political Attitudes and Democracy in Five Nations, Princeton, Princeton University Press, 1963.

8. James L. Gibson, Raymond M. Duch, and Kent L. Tedin, "Democratic Values and the Transformation of the Soviet Union", The Journal of Politics, Vol. 54, No. 2, 1992, pp. 329-371.

9. Robert Putnam, Making Democracy Work: Civic Traditions in Modern Italy, Princeton, Princeton University Press, 1993.

10. Samuel P. Huntington, "Democracy's Third Wave", Journal of Democracy, Vol. 2, 1992, pp. 12-35; Lucian W. Pye, The Mandarin and the Cadre: China's Political Cultures, Ann Arbor, Center for Chinese Studies, the University of Michigan, 1988; Lucian W. Pye, The Spirit of Chinese Politics, Cambridge, Harvard University Press, 1992; Lucian W. Pye and Mary W. Pye, Asian Power and Politics: The Cultural Dimensions of Authority, Cambridge, Harvard University Press, 1985.

11. Huntington, op. cit., p. 24.

12. Ogden, op. cit.

13. Nathan and Shi, op. cit.

14. Wang et al., op. cit.

15. Shi, op. cit.

16. Chen and Zhong, op. cit.

17. Gibson et al., op. cit.

18. Dowd et al., op. cit.

19. Russell J. Dalton and Doh Chull Shin, "Democratic Aspirations and Democratic Ideals", paper presented at the conference on "Citizens, Democracy and Markets around the Pacific Rim", Honolulu, East West Center, March 2004; Pippa Norris (ed.), Critical Citizens: Global Support for Democratic Government, New York, Oxford University Press, 1999, esp. chapters 2, 3, 7.

20. Dalton and Shin, op. cit., p. 8.

21. Nathan and Shi, op. cit.

22. Shi, op. cit., p. 557.

23. Chu and Chang, op. cit., p. 333.

24. Dowd et al., op. cit., p. 202.

25. Ibid, p. 202.

26. Ronald M. Glassman, China in Transition: Communism, Capitalism, and Democracy, New York, Praeger, 1991; Ronald M. Glassman, The New Middle Class and Democracy in Global Perspective, New York, St. Martin's Press, 1997.

27. Seymour M. Lipset, "Some Social Requisites of Democracy: Economic Development and Political Legitimacy”, American Political Science Review, Vol. 53, No. 1, 1959, pp. 69-105.

28. Barrington Jr. Moore, Social Origins of Dictatorship and Democracy: Lord and Peasant in the Making of the Modern World. Boston: Beacon Press, 1966. 
29. Glassman, The New Middle Class and Democracy in Global Perspective, op. cit.; Samuel P. Huntington, The Third Wave: Democratization in the Late Twentieth Century, Norman, University of Oklahoma Press, 1991.

30. Bian Yanjie, "Chinese Social Stratification and Social Mobility", Annual Review of Sociology, Vol. 28, 2002, pp. 91-116; Lu Xueyi (ed.), Dangdai Zhongguo shehui jieceng yanjiu baogao (Research Report on Contemporary China's Social Classes), Peking, Social Science Documentation Publishing House, 2002; Lu Xueyi (ed.), Dangdai Zhongguo shehui liudong (Social Mobility in Contemporary China), Peking, Social Science Documentation Publishing House, 2004; Li Peilin, Li Qiang and Sun Liping (eds.), Zhongguo shehui fenceng (Social Stratification in China's Today), Peking, Social Science Documentation Publishing House, 2004; Zhou Xiaohong, "Zhongguo zhongchan jieji: heyi keneng yu heyi kewei? (China's Middle Class: Why Do They Rise and What Can They Do?)", Shehui xue (Sociology), Vol. 2, 2003; Zheng Hangsheng and Li Lulu (eds.), Dangdai Zhongguo chengshi shehui jiegou (Social Structure of the Cities in Contemporary China), Peking, Renmin University of China Press, 2004.

31. Glassman, The New Middle Class and Democracy in Global Perspective, op. cit. 32. For the private entrepreneurs, see Bruce Dickson, Red Capitalists in China: the Party, Private Entrepreneurs, and Prospects for Political Change, New York, Cambridge University Press, 2003, p. 135.

33. Ruth Berins Collier, Paths Toward Democracy: The Working Class and Elites in Western Europe and South America, Cambridge, Cambridge University Press, 1999; Dietrich Rueschemeyer, Evelyne Huber Stephens, and John D. Stephens, Capitalist Development and Democracy, Chicago, University of Chicago Press, 1992.

34. Rueschemeyer and Stephens, op. cit., p. 59.

35. Ibid., p. 46.

36. Lee Ching Kwan, "Pathways of Labor Insurgency", in Elizabeth J. Perry and Mark Selden (eds.), Chinese Society: Change, Conflict and Resistance, London, Routledge, 2000, pp. 41-61.

37. Martin King Whyte, “The Changing Role of Workers", in Merle Goldman and Roderick MacFarquhar (eds.), The Paradox of China's Post-Mao Reforms, Cambridge, Harvard University Press, 1999, pp. 173-196.

38. Lee Ching Kwan, op. cit.

39. Ibid; Whyte, op. cit.; Timothy Weston, “China's Labor Woes: Will the Workers Crash the Party?" in Timothy Weston and Lionel M. Jensen (eds.), China: Beyond the Headlines, Lanham, Rowman \& Littlefield Publishers, 2000, pp. 245-271.

40. Whyte, The Changing Role of Workers, p. 196.

41. Lee Ching Kwan, op. cit.

42. Ronald Inglehart, Miguel Basañez, Jaime Díez-Medrano, Loek Halman and Ruud Luijkx (eds.), Human Beliefs and Values: A Cross-Cultural Sourcebook Based on the 1999-2002 Values Surveys, Mexico, Siglo XXI Editores, 2004; Dalton and Shin, op. cit.

43. Dalton and Shin, op. cit.; Pippa Norris (ed.), op. cit.

44. Chen and Zhong, op. cit.

45. Dalton and Shin, op. cit.

46. For a complete discussion of the causes of DK responses in Chinese public opinion surveys, see Zhu Jian-Hua, “'I Don't Know' in Public Opinion Surveys in China: Individual and Contextual Causes of Item Non-Response", Journal of Contemporary China, Vol. 5, No. 12, 1996. 
47. David Goodman, "The New Middle Class”, in Merle Goldman and Roderick MacFarquhar (eds.), The Paradox of China's Post-Mao Reforms, Cambridge, Harvard University Press, 1999, pp. 241-261; Margaret M. Pearson, China's New Business Elite: The Political Consequences of Economic Reform, Berkeley, University of California Press, 1997; David Zweig, "Undemocratic Capitalism: China and the Limits of Economism", National Interest, Vol. 56, Summer 1999, pp. 63-72.

48. Goodman, op. cit., pp. 260-261.

49. Dickson, Red Capitalists in China; Goodman, The New Middle Class; Pearson, China's New Business Elite.

50. Edward Friedman, "Still Building the Nation: The Causes and Consequences of China's Patriotic Fervor”, in Hua Shiping (ed.), Chinese Political Culture, 1989-2000, Armonk, ME Sharpe, 2001, pp. 103-132; Suisheng Zhao, “'We are Patriots First and Democrats Second': The Rise of Chinese Nationalism in the 1990s", in Edward Friedman and Barrett L. McCormick (eds.), What if China doesn't Democratize? Implications for War and Peace, Armonk, M.E. Sharpe, 2000, pp. 21-48.

51. Zhao, "We are Patriots First and Democrats Second", op. cit., p. 22.

52. Pippa Norris (ed.), Critical Citizens, op. cit., esp. chapters 1, 2; Alfred L. Chan and Paul Nesbitt-Larking, "Critical Citizenship and Civil Society in Contemporary China", Canadian Journal of Political Science, Vol. 28, No. 2, 1995, pp. 293-309; Chen Jie, Popular Political Support in Urban China, Stanford, Stanford University Press, 2004.

53. The two indicators "fight for country" (0="No", 1="Yes") and "national pride" (coded 0="Not At All proud" and "Not Very Proud", 1="Very Proud" and "Quite Proud") are added to form a three-point scale of nationalism: $0=$ low nationalism; 2=medium nationalism; $3=$ high nationalism.

54. Rueschemeyer and al., op. cit.

55. Jonathan Unger and Anita Chan, "China, Corporatism, and the East Asian Model", The Australian Journal of Chinese Affairs, Vol. 33, 1995, pp. 29-53.

\section{ABSTRACTS}

This study confronts the results of the World Values Survey conducted in China in June 2001 with three theories on the origins of democratic values. It shows that Chinese people have rather high democratic aspirations. The Chinese middle class offers the highest level of support for democracy. The negative relation between age and democratic-value orientations confirms the generation-replacement theory. This study also shows that education plays a critical role in support of democracy. 